\title{
Hemocyte and Biochemical Changes of Antheraea mylitta D. Infected with Antheraea mylitta Cytoplasmic Polyhedrosis Virus (AmCPV)
}

\author{
K. P. Kiran Kumar ${ }^{1}$, G. P. Singh ${ }^{2}$ \\ Silkworm Pathology Laboratory, Central Tasar Research and Training Institute, Pisk nagri, Ranchi - 835303, India
}

\begin{abstract}
The hemocyte and biochemical changes in Antheraea mylitta after per oral inoculation of Cytoplasmic Polyhedrosis Virus $(A m C P V)$ was observed. The total haemocyte count $(\mathrm{THC})$ increased gradually from day $1\left(13650 / \mathrm{mm}^{3}\right) \mathrm{to}^{8}\left(16625 / \mathrm{mm}^{3}\right)$ in uninoculated silkworms kept as control. In AmCPV treated silkworm larvae the THC increased up to day $2\left(12700-14480 / \mathrm{mm}^{3}\right)$ of inoculation. Thereafter, a decrease was noticed from day $3-8\left(14350-3812 / \mathrm{mm}^{3}\right)$. The differential haemocyte count (DHC) was different in inoculated silkworms then the control lot of silkworms. In the haemolymph of control larvae the prohaemocyte, plasmatocytes and granulocytes were more in number whereas oenocytoids were less in number. The number of degenerated cells increased among treated lot up to $8^{\text {th }}$ days of post inoculation. The total protein content in the haemolymph of treated larvae during the first and second day was similar to that of control. On third day, the protein content increased among treated larvae. But from fourth day onwards, the protein content decreased $(20.25 \mathrm{mg} / \mathrm{ml})$ against control $(33.73 \mathrm{mg} / \mathrm{ml})$. The total carbohydrate content gradually increased during fifth instar in control lot larvae, whereas, it steadily increased up to $4^{\text {th }}$ day and then showed a down ward trend from $5^{\text {th }}$ day treated larvae. The total lipid content in the haemolymph decreased among treated larvae day 2 , whereas in control larvae, an increasing trend was noticed.
\end{abstract}

Keywords: Antheraea mylitta, AmCPV, Hemocyte and Biochemical

\section{Introduction}

Immune system includes certain types of blood cells. It also includes chemicals, carbohydrates, lipids and proteins. In insects, several types of haemocytes are observed in the haemolymph (Butt \& Shields, 1996). Saran et al. (2002) classified the blood cells in the silkworm, B. mori L. and A. mylitta in to six types viz. prohaemocytes, plasmatocytes, granulocytes, spherulocytes, imaginal spherulocytes and oenocytes. Proteins are the derivatives of high molecular weight polypeptides. They play a vital role in the formation of structures in organisms. Like carbohydrates and fats proteins also can be utilized for energy purpose. In silkworm, blood glucose level can be correlated to their level of metabolism, and is comparable with mammalian blood glucose. Lipids play an important role in the biochemical processes delaying growth and development of insects.

To date, reports on hemocyte and biochemical response in $A m C P V$ infected silkworm, A. mylitta are scanty. Hence, present investigation was conducted to study hemocyte and biochemical changes of Antheraea mylitta D. infected with Antheraea mylitta Cytoplasmic Polyhedrosis Virus $(\mathrm{AmCPV})$.

\section{Materials and Methods}

Cytoplasmic Polyhedrosis Virus (AmCPV) Inoculum

Cytoplasmic polyhedrosis virus was purified from diseased silkworm as suggested by Aizawa, (1971).

\section{Inoculation of $A m C P V$}

$A m C P V\left(1 \times 10^{5} \mathrm{PIB} / \mathrm{ml}\right.$. $)$ was smeared on to the Terminalia tomentosa (assan) leaves and fed to $4^{\text {th }}$ instar of Daba B.V eco race after $24 \mathrm{hr}$ of moult. The treated and controlled batches were reared in indoor rearing condition.

\section{Samples collection}

Every day from 0 to $8^{\text {th }}$ day 6 larvae/day were collected from each replication, the haemolymph from all the 6 larvae was collected in to three eppendoff tubes (2 larvae haemolymph/tube) on ice and stored at $4^{\circ} \mathrm{C}$. A total of 6 tubes represented 3 replication collections.

\section{Estimation of haemocytes count}

Every day total haemocyte count (THC) estimation in the haemolymph of treated and control batches was determined following the method described by Tauber and Yeager (1935) using haemocytometer. The THC per $\mathrm{mm}^{3}$ of haemolymph was estimated according to the formula suggested by Jonesh (1962). Different haemocytes were identified based on the morphological features as described by Nittono (1960). The observations were made on THC and DHC counts.

\section{Estimation of biochemicals}

The total protein, total carbohydrate and total lipid content in hemolymph was estimated by the method of Lowry et al. (1951), phenol-sulphuric acid method - Dubois et al., 1956 and Folch et al., 1951, respectively.

\section{Annalysis of data}

Data recorded for THC and DHC counts, total protein, total carbohydrate and total lipid content were statistically analyzed using Completely Randomized Design (Snedecor and Cockron, 1971).

\section{Results and Discussion}

\section{Total Haemocyte Counts (THC)}

The total hemocyte count in the control silkworm increased from $1^{\text {st }}$ day to $6^{\text {th }}$ day and decreased on $7^{\text {th }}$ and $8^{\text {th }}$ day. In the control, total hemocyte counts was $13650 / \mathrm{mm}^{3}$ and 


\section{International Journal of Science and Research (IJSR) \\ ISSN (Online): 2319-7064 \\ Index Copernicus Value (2013): 6.14 | Impact Factor (2014): 5.611}

increased to $17702 / \mathrm{mm}^{3}$ by $6^{\text {th }}$ day (Table 1$)$. On $7^{\text {th }}$ day total hemocyte count was $16878 / \mathrm{mm}^{3}$ and $8^{\text {th }}$ day the count was decreased to $16625 / \mathrm{mm}^{3}$. While in $A m C P V$ treated silkworm the count was increased after inoculation up to $2^{\text {nd }}$ day of infection and then there was a decrease for a period ranging from 3-8 days.

The present observations are in agreement with the earlier investigation that the number of haemocytes may increase
(Balavenkatasubaiah et al, 2001) and decrease (Gillium and Shimanuki, 1967) to counter foreign body when infected. The cellular responses to infection have been worked out in many insect by earlier workers (Horohove and Dunn, 1983). On the basis of the above findings of the earlier workers it is evident that CPV induce the defense response through multiplication of haemocytes as is indicated by the increase in total haemocyte counts of the hemolymph of the worms.

Table 1. Total haemocyte count in AmCPV treated and healthy silkworm, A. mylitta

\begin{tabular}{|c|c|c|c|c|c|c|c|c|}
\hline \multirow{2}{*}{ Treatment } & \multicolumn{8}{|c|}{ Days post inoculation } \\
\hline & 1 & 2 & 3 & 4 & 5 & 6 & 7 & 8 \\
\hline AmCPV treated & 12700 & 14480 & 14350 & 12671 & 9851 & 6203 & 5009 & 3812 \\
\hline control & 13650 & 12530 & 12982 & 14455 & 16670 & 17702 & 16878 & 16625 \\
\hline S.E. \pm & 131.26 & 141.51 & 126.07 & 105.82 & 155.98 & 1823.12 & 191.76 & 191.23 \\
\hline C. D. at $5 \%$ & 137.18 & 152.26 & 177.43 & 124.28 & 256.75 & 308.45 & 289.45 & 331.87 \\
\hline
\end{tabular}

\section{Differential Haemocyte Counts (DHC)}

In control hemocytes showed a gradual increasing trend during developmental period. The number of prohemocyte, plasmatocytes, granulocytes and spherulocytes viz. 22-35, 32- 38, 35-38 and 17-28, respectively in control (Table 2). While during progressive infection, the gradual decrease in number of prohemocyte, spherulocytes and oenocytoids viz. 28-12, 24-9 and 13-3 respectively was noticed in AmCPV treated batch. The plasmatocytes and granulocytes increased up to $3^{\text {rd }}$ day and decresing trend was observed from $5^{\text {th }}$ day onwards. The number of oenocytoid was less in both the treatments and ranged from 3 to 15 . Few vermiform cells synonyms of plasmatocyte were recorded in both treatment and control. The number of degenerated cells was comparatively less in control than the treated batch.

The number of prohemocyte decreased due to the conversion of prohemocyte to other types of haemocyte during course of infection and number of plasmatocytes and granulocytes increased as both are involved in defense mechanism against entry of pathogens.

Table 2. Differential haemocyte count in AmCPV treated and healthy silkworm, A. mylitta

\begin{tabular}{|c|c|c|c|c|c|c|c|c|c|}
\hline \multirow{2}{*}{ Treatment } & \multirow{2}{*}{ Haemocyte } & \multicolumn{8}{|c|}{ Days post inoculation } \\
\hline & & 1 & 2 & 3 & 4 & 5 & 6 & 7 & 8 \\
\hline \multirow{7}{*}{ AmCPV treated } & PR & 28 & 25 & 24 & 23 & 18 & 17 & 15 & 12 \\
\hline & PL & 33 & 39 & 44 & 42 & 38 & 35 & 32 & 25 \\
\hline & GR & 35 & 45 & 48 & 45 & 44 & 41 & 32 & 27 \\
\hline & SP & 24 & 20 & 18 & 17 & 15 & 14 & 12 & 9 \\
\hline & $\mathrm{OE}$ & 13 & 11 & 10 & 8 & 8 & 5 & 4 & 3 \\
\hline & VER & 1 & - & - & - & - & - & - & - \\
\hline & DEG & 22 & 24 & 25 & 26 & 30 & 37 & 39 & 42 \\
\hline \multirow{7}{*}{ Control } & PR & 22 & 25 & 27 & 29 & 30 & 33 & 34 & 35 \\
\hline & PL & 32 & 33 & 35 & 37 & 39 & 41 & 37 & 38 \\
\hline & GR & 35 & 36 & 38 & 39 & 42 & 40 & 38 & 38 \\
\hline & SP & 17 & 18 & 20 & 22 & 25 & 26 & 27 & 28 \\
\hline & $\mathrm{OE}$ & 5 & 6 & 8 & 10 & 10 & 12 & 13 & 15 \\
\hline & VER & - & - & - & - & 4 & 1 & - & - \\
\hline & DEG & 10 & 12 & 13 & 14 & 16 & 9 & 7 & 8 \\
\hline \multicolumn{2}{|c|}{$\begin{array}{l}\mathrm{PR}=\text { Prohaemocyte } \\
\mathrm{PL}=\text { Plasmatocyte }\end{array}$} & $\begin{array}{l}\mathrm{GR}= \\
\mathrm{SP}=\end{array}$ & $\begin{array}{l}\text { ocyte } \\
\text { ocyte }\end{array}$ & $\begin{array}{r}\mathrm{OE}= \\
\mathrm{VER}=\end{array}$ & $\begin{array}{l}\text { yytoic } \\
\text { orm }\end{array}$ & & ege & & \\
\hline
\end{tabular}

Biochemical changes in $A m C P V$ treated and control batches

\section{Total protein content}

The hemolymth protein in control silkworm increased gradually from $16.31 \mathrm{mg} / \mathrm{ml}$ on $1^{\text {st }}$ day to $33.73 \mathrm{mg} / \mathrm{ml}$ on day $8^{\text {th }}$ (Table 3$)$. In treated silkworm, the total hemolymph protein have shown increasing trend from $1^{\text {st }}(16.26 \mathrm{mg} / \mathrm{ml})$ to $3^{\text {rd }}$ day $(24.22 \mathrm{mg} / \mathrm{ml})$ and decreasing trend from $4^{\text {th }}$ day onwards and reached $20.25 \mathrm{mg} / \mathrm{ml}$ by $8^{\text {th }}$ day from the inoculation.
The results indicated that changes occured in the hemolymph protein, during the course of $A m C P V$ infection. The difference in hemolymph protein healthy silkworm and treated silkworm becames more pronounced as the diseases progresses. This would probably indicate that during infection the synthesis and release of proteins from fat bodies are greatly increased. There are reports of production of antimicrobial substances such as lectin, defensin and attacin with the entry of foreign bodies (Wago, 1995). 


\section{International Journal of Science and Research (IJSR) \\ ISSN (Online): 2319-7064}

Index Copernicus Value (2013): 6.14 | Impact Factor (2014): 5.611

Table 3: Total protein content in AmCPV treated and healthy silkworm, $A$. mylitta

\begin{tabular}{ccccccccc}
\hline & \multicolumn{7}{c}{ Total protein content $\mathbf{~ m g} / \mathbf{m l}$} \\
\cline { 2 - 10 } Treatment & $\mathbf{1}$ & $\mathbf{2}$ & $\mathbf{3}$ & $\mathbf{4}$ & $\mathbf{5}$ & $\mathbf{6}$ & $\mathbf{7}$ & $\mathbf{8}$ \\
\cline { 2 - 10 } & 16.26 & 20.14 & 24.22 & 23.58 & 22.16 & 21.59 & 20.98 & 20.25 \\
\hline AmCPV treated & 16.31 & 20.19 & 23.54 & 26.74 & 28.53 & 30.34 & 32.83 & 33.73 \\
Control & 0.21 & 0.28 & 0.19 & 1.37 & 0.48 & 0.52 & 0.41 & 0.56 \\
\hline S.E. \pm & 1.92 & 1.27 & 1.21 & 1.52 & 1.68 & 1.93 & 2.64 & 2.15 \\
C. D. at 5\% & &
\end{tabular}

Total carbohydrate and total lipid contents

The hemolymph carbohydrate in control silkworm increased gradually from $6.75 \mathrm{mg} / \mathrm{ml}$ on $1^{\text {st }}$ day to $11.12 \mathrm{mg} / \mathrm{ml}$ on day $8^{\text {th }}$ (Table 4). In inoculated silkworm, the total hemolymph carbohydrate have shown increasing trend from $1^{\text {st }}(6.73$ $\mathrm{mg} / \mathrm{ml})$ to $6^{\text {th }}$ day $(8.05 \mathrm{mg} / \mathrm{ml})$ and decreasing trend from $7^{\text {th }}$ day onwards and reached $7.56 \mathrm{mg} / \mathrm{ml}$ by $8^{\text {th }}$ day from the treatement.

Table 4: Total carbohydrate content in AmCPVtreated and healthy silkworm, A. mylitta

\begin{tabular}{ccccccccc}
\hline & \multicolumn{7}{c}{ Total carbohydrate content $\mathbf{~ m g / m l}$} \\
\cline { 2 - 10 } Treatment & $\mathbf{1}$ & $\mathbf{2}$ & $\mathbf{3}$ & $\mathbf{4}$ & $\mathbf{5}$ & $\mathbf{6}$ & $\mathbf{7}$ & $\mathbf{8}$ \\
\cline { 2 - 9 } & 6.73 & 6.98 & 7.83 & 8.31 & 8.2 & 8.05 & 7.93 & 7.56 \\
\hline AmCPV treated & 6.75 & 7.02 & 7.89 & 8.42 & 9.86 & 10.51 & 10.69 & 11.12 \\
Control & 0.19 & 0.27 & 0.19 & 1.36 & 0.46 & 0.51 & 0.42 & 0.57 \\
\hline S.E. \pm & 1.91 & 1.26 & 1.21 & 1.51 & 1.64 & 1.93 & 2.61 & 2.14 \\
C. D. at 5\% & & &
\end{tabular}

The hemolymph lipid in control silkworm increased gradually from $10.22 \mathrm{mg} / \mathrm{ml}$ on $1^{\text {st }}$ day to $12.85 \mathrm{mg} / \mathrm{ml}$ on day $8^{\text {th }}$ (Table 5). In inoculated silkworm, the total hemolymph lipid have shown increasing trend from $1^{\text {st }}$
$(10.18 \mathrm{mg} / \mathrm{ml})$ to $4^{\text {th }}$ day $(10.12 \mathrm{mg} / \mathrm{ml})$ and decreasing trend from $5^{\text {th }}$ day onwards and reached $9.20 \mathrm{mg} / \mathrm{ml}$ by $8^{\text {th }}$ day from the treatment.

Table 5: Total lipid content in AmCPV treated and healthy silkworm, A. mylitta

\begin{tabular}{ccccccccc}
\hline & \multicolumn{7}{c}{ Total lipid content $\mathbf{~ m g} / \mathbf{m l}$} \\
\cline { 2 - 10 } Treatment & $\mathbf{1}$ & $\mathbf{2}$ & $\mathbf{3}$ & $\mathbf{4}$ & $\mathbf{5}$ & $\mathbf{6}$ & $\mathbf{7}$ & $\mathbf{8}$ \\
\cline { 2 - 10 } & 10.18 & 10.59 & 10.25 & 10.12 & 9.88 & 9.73 & 9.51 & 9.20 \\
\hline AmCPV treated & 10.22 & 10.63 & 11.15 & 11.84 & 12.38 & 12.65 & 12.72 & 12.85 \\
Control & 0.21 & 0.27 & 0.19 & 1.36 & 0.49 & 0.52 & 0.42 & 0.57 \\
\hline S.E. \pm & 1.93 & 1.27 & 1.21 & 1.52 & 1.71 & 1.94 & 2.62 & 2.13 \\
C. D. at 5\% & & &
\end{tabular}

The total carbohydrate and lipid contents increased to certain level and decreased steadily as the disease developed and it is reasonable to assume that as the disease progresses the number of pathogens increases and carbohydrates and lipids were utilized as a source of energy required for the growth and development of $A m C P V$.

\section{Inference}

The total haemocyte count (THC) increases gradually in healthy silkworm where as in $A m C P V$ infected silkworm larvae in initial stages THC increases there after decreases. In the healthy larvae the prohaemocyte, plasmatocytes and granulocytes will be more in number whereas oenocytoids were less in number. The number of degenerated cells increases as the intensity of the disease increases. In initial infection of $A m C P V$, total protein, carbohydrate and lipid contents will be improved as like healthy silkworm but, when disease enhances it shows down ward trend.

\section{References}

[17] Aizawa, K. (1971) Structure of polyhedra and virus particles of cytoplasmic polyhedrosis, In the cytoplasmic polyhedrosis of the silkworm (Eds: Aruga, H. and Tanada, Y.) Univ. Tokyo press, Tokyo, pp. 2336.

[18] Balavenkatasubbaiah, M., Natraju, B., Thiagrajan, V. and Datta, R.K. (2001) Haemocyte counts in different breeds of silkworm, Bombyx mori L., and their changes during progressive infection of BmNPV. Indian $J$. Seric., 40(2), 158-162

[19]Butt, T.M. and Shields, S.K. (1996) The structure and behaviour of gypsy moth (Lymantria dispar) haemocytes. J. Invertebr. Pathol., 68, 1-14.

[20] Dubois, M., Gilles, K. E., Hamilton, J.K., Rebers, P.A and Smith, F (1956) Calorimetric method of determination of sugars and related substances, Anal. Chem., 28, 350-356.

[21] Folch, I., Ascoli, I., Less, M., Meath, J.A. and Le Baron, F.N (1951) Preparation of lipid extracts from brain tissue. J. Biol. Chem. 191, 833-841. 


\section{International Journal of Science and Research (IJSR) \\ ISSN (Online): 2319-7064}

Index Copernicus Value (2013): 6.14 | Impact Factor (2014): 5.611

[22] Gilium, M. and Shimanuki H. (1967) In vitro phagocytosis of Nosema apis spores by honey bee haemocytes. J. Invertebr. Pathol., 9, 387-389.

[23] Horohov, D.W. and Dunn, P.E. (1983) Phagocytosis and nodule formation by hemocytes of Manduca sexta larvae following injection of Pseudomonas aeruginosa. J. Invertebr. Pathol., 41, 203-213

[24] Jonesh, J.C. (1962) Current concepts concerning insect hemocytes Am. Zool., 2, 209-246

[25] Lowry, O.H., Roserbrough, N.J., Farr, A.L. and Randal, R.J. (1951) Protein measurement with the folin-phenol reagent. J. Biol. Chem. 193, 265-275.

[26] Nittono, Y. (1960) Studies on the blood cells in the silkworm, Bombyx mori L. Bull. Seric. Expt. Stn., 16, 261-266.

[27] Saran, S.K., Mishra, P.K., Kumar, D., Singh, B.M.K., Sinha, B.R.R.P., Rai, S. and Pandey, P.N. (2002) Effect of total and differential haemocyte counts due to infection of Nosema species in Antheraea mylitta D.(Lepidoptera: Saturniidae) larvae. XIXth Congress of the International Sericultural Commission Proceedings. $21^{\text {st }}-25^{\text {th }}$ Sept., Bangkok, Thailand. pp $308-311$.

[28] Snedecor, G.W. and Cockron, W.E. (1971) Statistical Methods. Oxford IHB Publishing Co. New Delhi, pp. $339-361$.

[29] Tauber, O.E. and Yeager, J.E (1935) On the total blood counts of insects. I. Orthoptera, Odonata, Hemiptera and Homoptera. Ann. Entomol. Soc. Am., 28, 229-240.

[30] Wago, H. (1995) Host defense reaction of insects. Appl. Ent. Zool. 39. 